\title{
Effect of potato (Solanum tuberosum) meal on broiler production
}

\author{
N Sakib ${ }^{1}$, F Sultana², MAR Howlider ${ }^{2}$, MS Rana* ${ }^{1}$ \\ ${ }^{1}$ Poultry Production Research Division, Bangladesh Livestock Research Institute, Savar, Dhaka; ${ }^{2}$ Department of \\ Poultry Science, Bangladesh Agricultural University, Mymensingh 2202, Bangladesh
}

\begin{abstract}
The study was conducted to find out the performance of broiler birds fed different levels of potato meal (PM). The levels of potato meal in the different treatment rations were control $0,5,10$, and $15 \mathrm{~g} / \mathrm{kg}$, respectively. Dietary levels of PM did not affect live weight at 7, 21, 28, 35 and 42 days of age. However, live weight of broiler differed significantly $(p<0.05)$ among different levels of PM in the diet at 14 days of age and increasing level of PM had a tendency to decrease live weight between 7 and 14 days of age. Feed intake increased linearly with the increasing level of dietary PM $(p<0.05)$ up to 35 days of age followed by a decline at 42 days of age. At 14 days of age, feed intake in control diet and $10 \mathrm{~g}$ PM diets were similar and intermediate, it was highest in $15 \mathrm{~g}$ PM and lowest on $5 \mathrm{~g}$ PM diet. However, feed intake did not differ ( $p>0.05$ ) among different levels of PM in diet at 21, 28, 35, and 42 days of age. Feed conversion ratio (FCR) decreased between 7 and 14 days of age with the least conversion observed at $15 \mathrm{~g} / \mathrm{kg}$ PM level. FCR didn't differ significantly $(p<0.05)$ among different levels of PM in diet. Mortality did not alter due to the increasing levels of PM regardless of age of broiler. Dietary PM did not modify the dressing yield, breast meat, thigh meat and other carcass traits. Feed cost in different dietary PM groups were more or less similar, whereas total production cost per $\mathrm{kg}$ broiler were increased in $10 \%$ Potato Meal than control $(\mathrm{p}<0.05)$. However, sale price $(\mathrm{Taka} / \mathrm{broiler})$ and sale price $(\mathrm{Taka} / \mathrm{kg}$ broiler) were more or less similar in all treatments. Profit per broiler and per $\mathrm{kg}$ broiler were reduced as the PM level increased in the diet. It was therefore concluded that use of potato meal at 5 to $15 \mathrm{~g} / \mathrm{kg} \mathrm{diet}$ may not be suitable for growth and profitability in broiler production.
\end{abstract}

Key words: Broiler, dressing yield, FCR, potato meal

Bangladesh Animal Husbandry Association. All rights reserved. Bang. J. Anim. Sci. 2014.43 (3): $192-196$

\section{Introduction}

One of the major problems facing the broiler industry today, particularly the broiler production is the high cost of feeds resulting from shortage of high energy grains (Mmereole 1996; Mmereole 2008). The grains are known to constitute 60$70 \%$ of the broiler feed (Ekenyem 2007). The high cost of grains are due largely to competition for grains between livestock and human. Some low-income and food deficit countries (LIFDC) have shut down their broiler farms due to high cost of broiler feeds (Ekenyem 2007). Traditional broiler diet is formulated with high proportion of grains. Maize has traditionally been the ingredient of choice for the supply of energy in monogastric animal diets with inclusion levels of $50-70 \%$ (PAN 1995). It accounts for $18 \%$ of the world cereal acreage and about $25 \%$ of the world cereal production (Haque 1996). In the year of 20032004 the local production of Wheat and Maize are 1497105 ton and 38055 ton (Hasan et al. 2008) which cannot meet up the demand of human, broiler and livestock. As a result, huge grain is imported each year using hard earn foreign currency. Moreover, use of costly imported grains in diet increases feed cost high enough to limit broiler rearing. Therefore, nutritionists are suggesting to use cheaper unconventional locally available substitute to grains like Cassava Tuber Meal (CTM), potato meal for increasing profitability (Rahman and Reza 1983; Hossain et al. 1989). The high cost of energy sources like maize and wheat for broiler diet has been the main cause of the high cost broiler products especially in developing countries. To arrest this situation, broiler raising all over the world and those of developing countries are forced to think 
of those plants that can be easily grown and yield more per unit area as compared to maize for inclusions in broiler rations. Potato (Solanum tuberosum) is one of the most important food crops grown all over the world, a significant source of energy for 4000 million people mainly in Asia. It is an unconventional feed ingredient for broiler. Potato has a high production potential (fresh tuber yield, 20 tons/ha) whereas maize and wheat yielded 5 tons/ha and 7 tons/ha, respectively and can adapt to different types of soils. It is an energy source which could substitute maize or other cereals used for feeding broiler. Potato Meal (PM) may be used as an energy value of more than $2830 \mathrm{ME}$ per $\mathrm{kg}$. According to composition values, potato meal (PM) contains more than $65 \%$ starch, $6.74 \%$ ash, $12.72 \% \mathrm{CP}, 23.48 \% \mathrm{CF}$, and $0.99 \% \mathrm{EE}$ on $\mathrm{DM}$ basis. PM has been reported to be cheaper than maize and wheat (PAN 1995). Moreover, huge amount of potato are being wasted due to lack of adequate number of cold storage in the country. Considering the above points for reducing competition with human consumption and make the energy source available, potato was partially used with the basal feed to replace the maize that reduces the cost of production of broiler.

\section{Materials and Methods}

The experiment was conducted with 96, straight run Cobb 500 commercial broilers during 14-42 days of age at Bangladesh Agricultural University (BAU) Poultry Farm, Mymensingh.

Potatoes were collected from a local market. After proper washing and cleaning of soil and dust, skins were removed and the flesh was cut in desirable pieces $(2 \mathrm{~mm})$. Then pieces of raw potato were spread on clean polythene for sun drying. To prevent the formation of fungus during drying of potato, proper care was taken. After sun drying potato was ground mechanically. The ground potato was kept in airtight polythene bags until used in feed preparation. Polythene bags were used for short term storage of potato meal.These bags also helped to prevent spoilage from insect and fungus formation. Approximately $20 \mathrm{~kg}$ PM was used.

The experiment was conducted in an open sided a gable type tin-shed house. The house was partitioned into 16 pens using wire-net (38cm height) where a group of 6 broilers were randomly allocated to each pen. Each pen was $257 \mathrm{~cm} \times 64 \mathrm{~cm}$ and was allotted for 6 broilers. Therefore, floor space for each broiler was 3433 $\mathrm{cm}^{2}$. One trough $(90 \mathrm{~cm} \times 11.5 \mathrm{~cm} \times 6 \mathrm{~cm})$ feeder and one pot drinker with a capacity of one litter were provided in each pen up to 42 weeks. The experimental rooms in the broiler house were properly washed and cleaned by using tap water and disinfected by using disinfectant Iosan.

The chicks were collected from a local market (dealer) in Mymensingh district. They were equally and randomly divided and assigned to four dietary treatments $(0,5,10$ and $15 \mathrm{~g} / \mathrm{kg}$ PM) with four replications for each treatment. Each treatment consisted of 24 birds and distributed into four replicated pens each of 6 broilers. The broilers were given a starter diet followed by a grower diet up to 42 days of age.

Feeders were cleaned every week and drinkers were cleaned every morning. Fresh clean drinking water was provided twice daily up to 42 days (7AM, 6PM). Fresh and dried rice husk was used as litter at a depth of about $3 \mathrm{~cm}$. The nutrient requirements of the birds were satisfied as per recommendation of BSTI (1988) feeding standard. Feed and water were supplied ad libitum to the broilers. The broilers were exposed to a continuous lighting of 23 hours and 30 minutes and a dark period of 30 minutes in each 24 hours. Electric bulbs were used for lighting. The experiment was conducted in summer (23 April to $5 \mathrm{~J}$ une). The chicks were brooded up to one week. During the early period of brooding the environmental temperature was lower than the required brooding temperature. Therefore, additional heat was provided to chicks by using 100-watt electrical bulbs in the respective pens. Strict sanitary measures were taken during the experimental 


\section{Potato meal in broiler diet}

period. The temperature of the house was recorded 3 times a day (7AM, 12PM and 6PM) and the relative humidity of the house was also recorded 3 times of a day (7AM, 12PM and $6 \mathrm{PM})$ by using hygro-thermometer. A vaccination schedule was followed during the experimental period. All vaccines were applied by following manufacturer's instruction.

At the end of the experiment, 16 broilers; one broiler (straight run) from each plot ( 4 diets $\times 4$ replications), weighing average of pen weight were selected to determine meat yield characteristics. To facilitate processing, all birds had their feed and water withheld 12 hours prior to killing. After complete bleeding, the slaughtered broilers were immersed in water heated to $51-55^{\circ} \mathrm{C}$ for 120 seconds in order to loosen the feathers of the carcass. Final processing was performed by removal of the head, shanks, viscera, oil gland, kidneys and lungs of the carcasses.

Cost of production was included considering expenses on chicks, feed and other costs (other costs included vaccine, labour, transport, litter, electricity, water, etc). Chick cost was that of purchasing cost. Feed cost was calculated on the basis of market price of the ingredients. Litter cost was calculated on the basis of market price saw dust.

All recorded and calculated data were statistically analyzed using analysis of variance technique by a computer using a SAS statistical computer package program in accordance with the principles of Completely Randomized Design. The LSD were calculated to compare variations among diets where ANOVA showed significant differences.

\section{Results and Discussion}

Live weight of broilers did not differ significantly among the diet groups except at 14 days of old. Increasing level of PM decreased live weight at $7,21,28,35$ and 42 days of age although the differences were not significant.
Kratzer et al. (1987) observed decreased live weight with increasing proportion of $\mathrm{PM}$ in diet. They observed that diet with $20 \%$ PM reduced live weight. However, the increasing level PM might have failed to correct the nutritive value at most of the ages because raw potato contains some anti- nutritional factors that caused low dry matter digestibility, though the diet contains adequate high quality protein in the feed (Gerpacio et al. 1978).

Feed intake increased linearly with increasing level of dietary PM $(p<0.05)$ up to 35 days of age followed by a decline at 42 days of age (Table 1). At 14 days of age, feed intake on control diet and $10 \mathrm{~g}$ PM diets were similar and intermediate, highest on $15 \mathrm{~g} P M$ and lowest on $5 \mathrm{~g}$ PM diet. However, feed intake did not differ $(P>0.05)$ among different levels of PM in diet at $7,21,28,35$, and 42 days of age. Kratzer et al. (1987) observed that feed intake increased linearly with the increased proportion of PM in the diet.

FCR decreased at 7 and 14 days of age with the least conversion observed at $15 \mathrm{~g} / \mathrm{kg}$ PM (Table $1)$. FCR did not differ $(p<0.05)$ among different levels of PM in the diet. Gradual decrease of feed conversion ratio ( $F C R$ ) regardless of age for an increase of dietary PM is supported by Kratzer et al. (1987). They observed decreasing FCR on increasing PM proportion in diet. PM does not affect directly on growth and feed intake at 21 , 28, 35 and 42 days.

There was no difference in mortality which could be explained by dietary PM at all ages in broiler (Table 1 ). The results agreed with Akintala et al. (2002). Dietary PM could not modify the dressing yield, breast meat, thigh meat and variation in other parameters (Table 2), irrespective of age. This result was in accordance with Awojobi and Adekunmi (2002).

Feed cost was highest in $15 \mathrm{~g} / \mathrm{kg}$ dietary PM group, whereas total production cost per $\mathrm{kg}$ broiler was increased by $10 \%$ PM than control $(0 \%)$ and other PM groups $(p<0.05)$ (Table 3). However, sale price (Tk./broiler) 
and sale (Tk./kg broiler) were more or less similar in all other treatments. Profit per broiler and per $\mathrm{kg}$ broiler was highest on control diet $(p<0.05)$. On the other hand, there was no difference $(p>0.05)$ in cost $/ \mathrm{kg}$ diet at different level of Potato meal.

Table 1. Effect of different dietary levels of potato meal (PM) $(\mathrm{g} / \mathrm{kg})$ on growth performance of commercial broilers at different ages

\begin{tabular}{|c|c|c|c|c|c|}
\hline \multirow{2}{*}{ Parameter } & \multirow{2}{*}{$\begin{array}{l}\text { Age } \\
\text { (day) }\end{array}$} & \multicolumn{4}{|c|}{ Dietary potato meal $(\mathrm{g} / \mathrm{kg})$} \\
\hline & & 0 & 5 & 10 & 15 \\
\hline \multirow{7}{*}{$\begin{array}{l}\text { Cumulative } \\
\text { Live weight } \\
(\mathrm{g} / \mathrm{kg})\end{array}$} & 0 & 44.25 & 44.49 & 44.52 & 44.30 \\
\hline & 7 & 138.66 & 137.25 & 131.25 & 129.50 \\
\hline & 14 & $311.00^{a}$ & $310.50^{a}$ & $274.50^{b}$ & $284.75^{\mathrm{ab}}$ \\
\hline & 21 & 464.75 & 451.25 & 459.50 & 450.75 \\
\hline & 28 & 711.25 & 641.25 & 668.75 & 646.00 \\
\hline & 35 & 954.66 & 861.00 & 881.25 & 845.50 \\
\hline & 42 & 1150.00 & 1083.00 & 1099.75 & 1088.75 \\
\hline \multirow{6}{*}{$\begin{array}{l}\text { Feed } \\
\text { intake } \\
(\mathrm{g} / \mathrm{kg})\end{array}$} & 7 & 181.54 & 173.00 & 161.25 & 163.00 \\
\hline & 14 & $309.50^{\mathrm{ab}}$ & $288.25^{b}$ & $311.50^{\mathrm{ab}}$ & $334.75^{a}$ \\
\hline & 21 & 428.75 & 418.00 & 445.00 & 406.50 \\
\hline & 28 & 595.75 & 528.25 & 562.25 & 636.75 \\
\hline & 35 & 694.25 & 656.00 & 649.00 & 671.00 \\
\hline & 42 & 460.50 & 481.25 & 514.50 & 499.25 \\
\hline \multirow{6}{*}{$\begin{array}{l}\text { Cumulative } \\
\text { Feed } \\
\text { conversion } \\
\text { ratio (FCR) }\end{array}$} & 7 & 1.91 & 1.78 & 1.86 & 1.91 \\
\hline & 14 & $1.84^{a b}$ & $1.73^{b}$ & $1.97 \mathrm{ab}$ & $2.06^{a}$ \\
\hline & 21 & 2.18 & 2.16 & 2.25 & 2.17 \\
\hline & 28 & 2.27 & 2.32 & 2.35 & 2.49 \\
\hline & 35 & 2.40 & 2.63 & 2.58 & 2.46 \\
\hline & 42 & 2.47 & 2.56 & 2.45 & 2.63 \\
\hline \multirow{6}{*}{$\begin{array}{l}\text { Mortality } \\
(\%)\end{array}$} & 7 & 0 & 0 & 0 & 0 \\
\hline & 14 & 0 & 0 & 0 & 4.17 \\
\hline & 21 & 4.17 & 0 & 0 & 0 \\
\hline & 28 & 0 & 4.17 & 0 & 0 \\
\hline & 35 & 0 & 0 & 0 & 4.17 \\
\hline & 42 & 0 & 0 & 0 & 0 \\
\hline
\end{tabular}

Means with different superscript in the same row differ significantly $(* *, p<0.01)$

A gradual increase in production cost (Table 3 ) due to increase of dietary PM was in agreement with Maust et al. (2005). They observed that production cost (Tk./kg broiler) increased with the increased proportion of PM in the diet. They further suggested lower biological value of PM was responsible for increased production cost (Tk./kg broiler) by increasing dietary concentration of PM. The result of this study suggested that rearing of broiler on PM based diet reduced profit.

Table 2. Meat yield characteristics at 42 days of age of broilers fed different level of dietary potato meal (PM) $(\mathrm{g} / \mathrm{kg})$

\begin{tabular}{lrrrr}
\hline \multirow{2}{*}{ Variables } & \multicolumn{4}{c}{ Dietary potato meal $(\mathrm{g} / \mathrm{kg})$} \\
\cline { 2 - 5 } & \multicolumn{1}{c}{0} & \multicolumn{1}{c}{5} & \multicolumn{1}{c}{10} & \multicolumn{1}{c}{15} \\
\hline Live weight (g) & 1120.50 & 1198.75 & 1198.00 & 1181.25 \\
BLW (\%) & 4.59 & 3.75 & 4.15 & 4.57 \\
FLW (\%) & 6.73 & 7.8 & 7.47 & 7.07 \\
Head weight (\%) & 2.80 & 2.62 & 2.66 & 2.63 \\
Neck weight (\%) & 2.01 & 1.93 & 1.97 & 2.45 \\
Thigh weight (\%) & 8.84 & 9.49 & 9.20 & 8.99 \\
Back weight (\%) & 9.33 & 9.26 & 9.67 & 9.69 \\
Giblet weight (\%) & 5.94 & 5.92 & 6.19 & 5.95 \\
Drumstick weight (\%) & 7.86 & 7.87 & 8.44 & 8.68 \\
Wing weight (\%) & 8.44 & 7.60 & 8.12 & 8.39 \\
Breast weight (\%) & 9.98 & 10.10 & 10.21 & 10.44 \\
Viscera weight (\%) & 8.80 & 8.95 & 9.15 & 8.96 \\
Dressing \% & 51.55 & 50.10 & 51.65 & 51.17 \\
\hline
\end{tabular}

BLW, blood loss weight; FLW, feather loss weight

Table 3. Production cost and profit (Tk.) of broiler on dietary potato meal (PM) ( $\mathrm{g} / \mathrm{kg}$ ) at marketing (42 days)

\begin{tabular}{lrrrr}
\hline \multirow{2}{*}{ Parameters } & \multicolumn{4}{c}{ Dietary potato meal (g/kg) } \\
\cline { 2 - 5 } & \multicolumn{1}{c}{0} & \multicolumn{1}{c}{5} & \multicolumn{1}{c}{10} & \multicolumn{1}{c}{15} \\
\hline Feed cost (Tk./kg broiler) & 52 & 55 & 58 & 62 \\
Total cost (Tk./broiler) & $134^{\mathrm{c}}$ & $141^{\mathrm{bc}}$ & $146^{\mathrm{ab}}$ & $153^{\mathrm{a}}$ \\
Total cost (Tk./kg broiler) & $112^{\mathrm{c}}$ & $117^{\mathrm{bc}}$ & $124^{\mathrm{a}}$ & $121^{\mathrm{ab}}$ \\
Sale price (Tk./broiler) & 148 & 150 & 147.5 & 155.25 \\
Sale price (Tk./kg live broiler) & 125 & 125 & 125 & 125 \\
Profit (Tk./broiler) & $14^{\mathrm{a}}$ & $9^{\mathrm{ab}}$ & $1.5^{\mathrm{c}}$ & $1.75^{\mathrm{bc}}$ \\
Profit (Tk./kg broiler) & $13^{\mathrm{a}}$ & $8^{\mathrm{ab}}$ & $1.0^{\mathrm{c}}$ & $1.5^{\mathrm{bc}}$ \\
\hline
\end{tabular}

Means with different superscript in the same row differ significantly $(p<0.05)$

\section{Conclusions}

It may be suggested that potato meal may not be a good substitute to grain for feeding broilers.

\section{References}

Akintala EO, Aderibigbe AO, Matanmi O (2002). Evaluation of the nutritive value of cassava tuber meal as replacement for maize in the 


\section{Potato meal in broiler diet}

starter diets for broiler chicken, Cali, Colombia: CIPAV Foundation, 14: 1-6.

Awojobi HA, Adekunmi AA (2002). Performance of broilers fed graded levels of cassava tuber meal and sweet potato meal, New Delhi, India: Indian Council of Agricultural Research, 72: 1169-1172.

Ekenyem BU, (2007). Effect of dietary inclusion of 1pomea ascarifolia leaf meal on the performance of carcass and organ Characteristics of grower pigs. Advances in Science and Technology, P. 87-91.

Gerpacio AL, Pascual F, Querubin LJ, Vergel de Dio AF and Mercado CL (1978). Evaluation of tuber meals as energy sources. Sweet potato and cassava based rations for broilers. Philippine Agriculturalist 61: 395410.

Haque ABMM (1996). An Agribusiness Study on Winter Maize System in Some Selected Areas of Bangladesh. MSc Thesis, Department of Cooperation and Marketing, Bangladesh Agricultural University, Mymensingh.

Hasan MN, Monayemmiah MA, Islam MS, Alam QM and Hossain MI (2008). Change and instability in area and production of wheat and maize in Bangladesh. Bangladesh Journal of Agricultural Research, 33: 409417
Hossain MD, Bulbul SM, Howlider MAR (1989). The composition of some unconventional feeds. Poultry adviser, 22: 37-40.

Huque QME (2008). Poultry industry in Bangladesh and strategies for its improvement, Second International Poultry Show and Seminar, Word's Poultry Science Association of Bangladesh.

Maust LE (2005). Nutritive value of cassava plants for chicks, Poultry Science, 55: 329332.

Mmereole FUC (1996) The study haematological parameters in the Nigerian local chicken. Nigerian Journal of Animal Production, 1: 94-97.

Mmereole FUC (2008). Effects of replacing groundnut cake with rubber seed meal on the haematological and serological indces of broilers. International Journal of Poultry Science, 7: 622-624.

PAN (Poultry Association of Nigeria). 1995. Annual Reports, Poultry Association of Nigeria, Lagos, Nigeria, 33: 3437.

Rahman A, Reza MA (1983). Study on the effect of unconventional sources of protein and energy for poultry. MSc Thesis. Department of Animal Nutrition, Bangladesh Agricultural University, Mymensingh. 